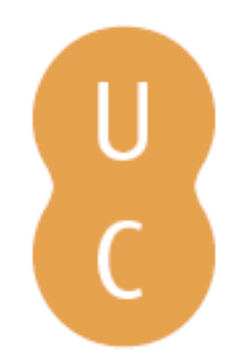

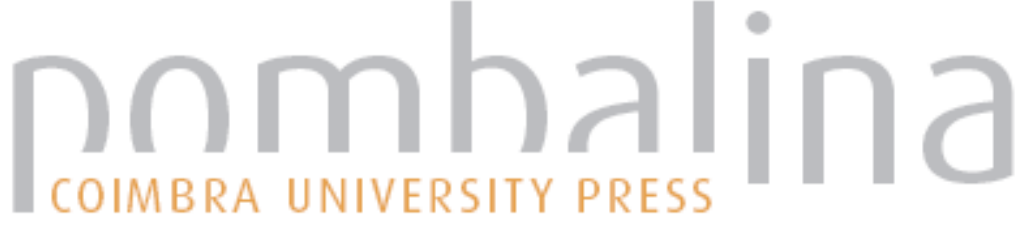

\section{A Inspecção das Bibliotecas e Arquivos e a ideologia do Estado Novo}

Autor(es): $\quad$ Ribeiro, Fernanda

Publicado por: Imprensa da Universidade de Coimbra

URL

persistente: URI:http://hdl.handle.net/10316.2/32211

DOI: $\quad$ DOI:http://dx.doi.org/10.14195/978-989-26-0810-5_15

Accessed : $\quad$ 26-Apr-2023 10:55:28

A navegação consulta e descarregamento dos títulos inseridos nas Bibliotecas Digitais UC Digitalis, UC Pombalina e UC Impactum, pressupõem a aceitação plena e sem reservas dos Termos e Condições de Uso destas Bibliotecas Digitais, disponíveis em https://digitalis.uc.pt/pt-pt/termos.

Conforme exposto nos referidos Termos e Condições de Uso, o descarregamento de títulos de acesso restrito requer uma licença válida de autorização devendo o utilizador aceder ao(s) documento(s) a partir de um endereço de IP da instituição detentora da supramencionada licença.

Ao utilizador é apenas permitido o descarregamento para uso pessoal, pelo que o emprego do(s) título(s) descarregado(s) para outro fim, designadamente comercial, carece de autorização do respetivo autor ou editor da obra.

Na medida em que todas as obras da UC Digitalis se encontram protegidas pelo Código do Direito de Autor e Direitos Conexos e demais legislação aplicável, toda a cópia, parcial ou total, deste documento, nos casos em que é legalmente admitida, deverá conter ou fazer-se acompanhar por este aviso. 


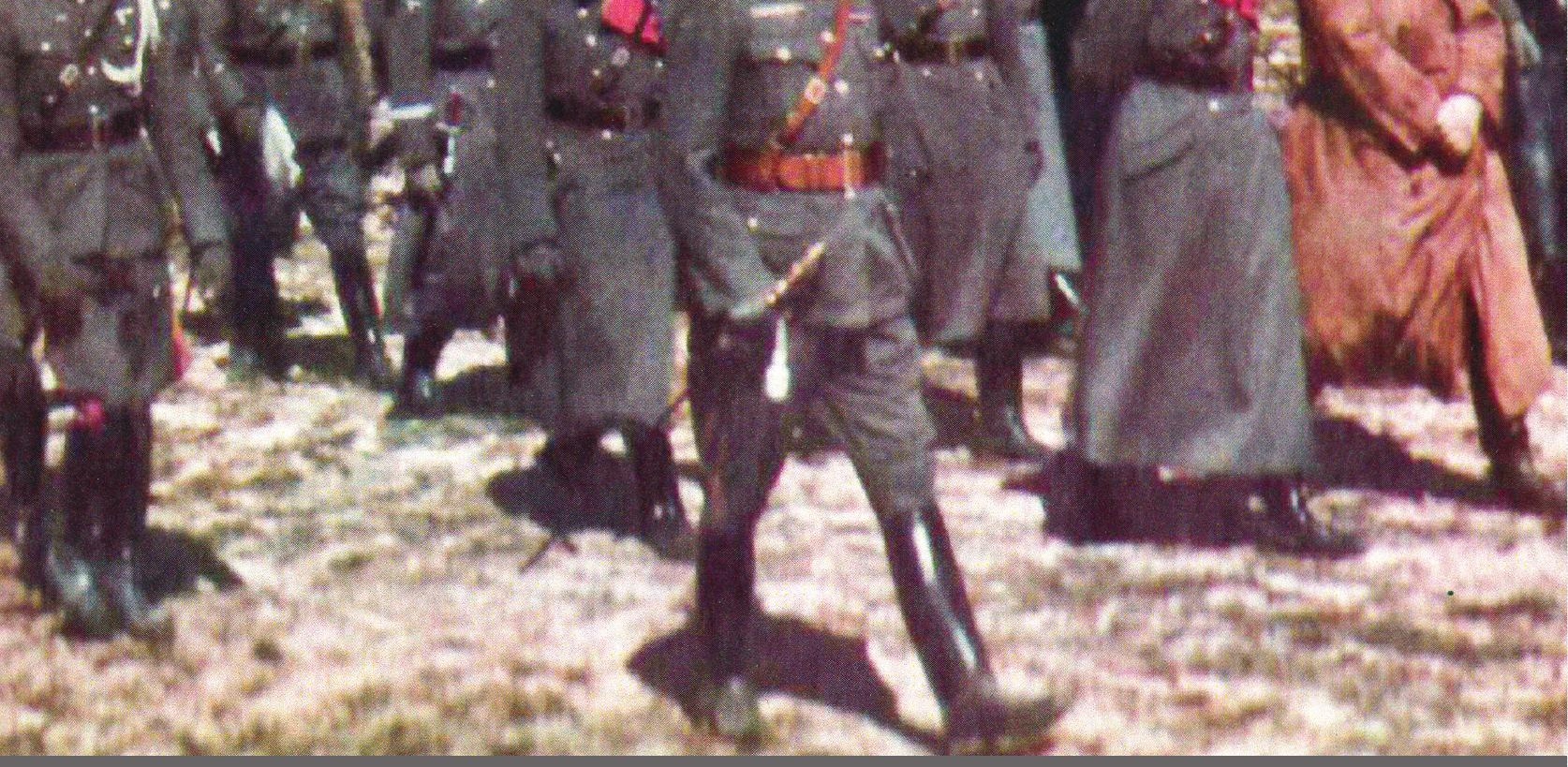

\section{Estados autoritários}

e totalitários

e suas representações

Coordenaação

Luís Reis Torgal

Heloísa Paulo

Coimbra · 2008

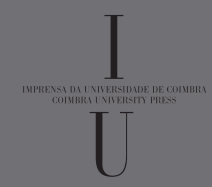




\section{Fernanda Ribeiro}

\section{A INSPECÇÃO DAS BIBLIOTECAS E ARQUIVOS E A IDEOLOGIA DO ESTADO NOVO}

\section{Da acção legislativa à dinâmica de intervenção}

A Inspecção-Geral das Bibliotecas e Arquivos Públicos, incumbida "da direcção e administração, ou da fiscalisação superior, dos archivos e das bibliothecas pertencentes ao estado a ás corporaçôes e instituições sujeitas á superintendência do estado ou por elle subsidiadas" foi criada ainda durante a vigência do regime monárquico, pelo Decreto de 29 de Dezembro de $1887^{1}$.

Este diploma regulava, do ponto de vista estatal e político, aquilo a que hoje poderíamos chamar os serviços públicos de informação/documentação e estabelecia as bases de um sistema que se manteve, nos seus fundamentos e nas suas linhas gerais, praticamente inalterado até algum tempo depois do 25 de Abril de 1974, mais concretamente até meados dos anos oitenta, altura em que as bibliotecas e os arquivos deixaram, definitivamente, de estar dependentes do Ministério da Educação para passarem a ser tutelados pela Secretaria de Estado da Cultura.

A actividade da Inspecção numa primeira fase não está particularmente documentada e, ao que se sabe através de escritos posteriores, a sua acção não foi muito significativa. A principal fonte conhecida, que permite lançar alguma luz sobre os primeiros anos de vida deste organismo, é uma "Memória", datada de 1892 e elaborada pelo então Inspector-Geral interino, Tomás Lino da Assunção, que foi escrita com o fim de ser apresentada ao Congresso Pedagógico Hispano-Português-Americano, que teve lugar em Madrid, nesse mesmo ano, e do qual foi vice-presidente Bernardino Machado ${ }^{2}$.

Este texto, bem como a legislação promulgada para o sector das bibliotecas e arquivos, são a expressão mais fiável da actividade da Inspecção numa primeira etapa da sua vida,

${ }^{1}$ PORTUGAL. Leis, decretos, etc. - Direcção Geral de Instrucção Pública: 1. ${ }^{a}$ Repartição: [Decreto de 29 de Dezembro de 1887]. Diário do Governo. Lisboa. 3 (4 Jan. 1888) 18.

${ }^{2}$ Cf.: ASSUNÇÃO, Tomás Lino da - Memoria da Inspecção Geral das Bibliothecas e Archivos Publicos. Ed. facsimile. Coord. Paula Lamego. Vila Nova de Famalicão : Câmara Municipal, Museu Bernardino Machado, 2004. (Manuscritos do Fundo Particular de Bernardino Machado). ISBN 972-9152-93-4. O manuscrito desta edição encontra-se no Museu Bernardino Machado, em Vila Nova de Famalicão. 
ou seja, até à implantação do regime republicano. Neste período, a Inspecção teve um papel particularmente importante na preparação de diplomas legislativos, destinados a regular o funcionamento dos organismos que tutelava, e empreendeu uma série de acções voltadas para a salvaguarda da documentação histórica. A partir das fontes disponíveis, percebemos claramente que a sua actividade no que respeita ao cumprimento da legislação sobre incorporações de fundos documentais de interesse histórico nos serviços sob a tutela do Estado foi, de facto, eficaz ${ }^{3}$. As incorporações foram a grande prioridade tendo os aspectos mais técnicos sido objecto de menor atenção, como se pode comprovar através do órgão oficial da instituição, que se publicou entre $1902 \mathrm{e}$ 1911, sob o título Boletim das Bibliotecas e Arquivos Nacionais.

A mudança de atitude e o incremento da acção verificaram-se após a instauração do novo regime. Com a implantação da República, a aposta política na área da instrução produziu, desde logo, alteraçôes ao quadro legal em que a Inspecção se inseria. Em 18 de Março de 1911, é promulgado um decreto que reorganiza os "serviços das Bibliotecas e Archivos Nacionaes, dependentes da Direcção Geral da Instrucção Secundaria, Superior e Especial", integrada no Ministério do Interior ${ }^{4}$, passando a haver dois inspectores, nomeados pelo Governo a título vitalício, um destinado à Inspecção das Bibliotecas Eruditas e Arquivos e outro à Inspecção das Bibliotecas Populares e Móveis. O extenso preâmbulo do diploma justifica ideologicamente as medidas legislativas que o mesmo encerra, inserindo esta reestruturação nos ideais caros aos republicanos.

$\mathrm{Na}$ verdade, durante o período cronológico correspondente à Primeira República, vamos assistir a um incremento notável das bibliotecas e dos arquivos, que é, por um lado, reflexo de novas orientações político-ideológicas e, por outro, fruto da acção de algumas personalidades como Júlio Dantas, António Ferrão e Raul Proença, que assumem responsabilidades importantes, do ponto de vista político, de gestão e de coordenação técnica.

O dinamismo que caracterizou o sector bibliotecário e arquivístico, protagonizado em grande medida pela Biblioteca Nacional, na fase em que Jaime Cortesão exerceu o cargo de director e em que a chefia dos Serviços Técnicos esteve entregue a Raul Proença, permitiu delinear e, em alguns casos, pôr em prática, projectos de grande envergadura, cuja concepção, do ponto de vista técnico, estava perfeitamente em consonância com os desenvolvimentos internacionais. A visão republicana para este sector de actividade,

3 O Decreto de 29 de Dezembro de 1887, que criou a Inspecção Geral das Bibliotecas e Arquivos Públicos, determinou que o limite cronológico, que balizava a incorporação de documentos históricos no Arquivo da Torre do Tombo, era alargado do ano de 1600 para 1834, estendendo-se a obrigatoriedade das incorporaçôes aos documentos "que houverem pertencido a tribunaes, repartições e estabelecimentos do estado actualmente extinctos, e aos que não forem necessarios ao serviço e expediente d'aquelles em cuja posse estejam" (ver: PORTUGAL. Leis, decretos, etc. - Direcção Geral de Instrucção Pública: $1 .^{\mathrm{a}}$ Repartição: [Decreto de 29 de Dezembro de 1887] (ob. cit.) art. 5. ${ }^{\text {) }}$.

${ }^{4}$ PORTUGAL. Leis, decretos, etc. - Ministério do Interior : Direcção Geral da Instrucção Secundária, Superior e Especial : [Decreto de 18 de Março de 1911]. Diário do Governo. Lisboa. 65 (21 Mar. 1911) p. 1.213-1.215.

Em 1913, pela Lei de 7 de Julho, é criado o Ministério da Instrução Pública, do qual passam a depender os serviços de instrução. Entre esses serviços contava-se a Direcção-Geral da Instrução Secundária, Superior e Especial, que este diploma extingue, passando os serviços das bibliotecas e arquivos do Estado a depender da Repartição de Instrução Artística. 
enquadrado no amplo campo da instrução pública foi, sem dúvida, muito fecunda em estudos, produção de textos e promulgação de leis com vista à afirmação de uma área considerada estratégica para o regime político em vigor. Contudo, a falta de meios financeiros e humanos obstou a que muitas das ideias e projectos republicanos tivessem uma concretização efectiva. Coarctadas na sua implementação foram, por exemplo, a rede de bibliotecas populares e móveis, que se pretendia alargar a todo o País, ou a criação da rede de arquivos distritais, que se projectara para cobrir toda a área de Portugal continental e ilhas adjacentes.

Ficava, porém, da herança republicana, um programa de acção bem delineado, um enquadramento legal, que denunciava uma visão moderna e prospectiva, e realizações efectivas, de elevado nível técnico, como foi o caso específico da reforma operada na Biblioteca Nacional. Neste contexto, o papel da Inspecção como organismo de tutela era valorizado ao nível político e na vertente técnica e administrativa, cabendo à figura do Inspector Júlio Dantas, nomeado em 1912, a responsabilidade máxima das acçôes empreendidas.

\section{Dos constrangimentos ideológicos à manutenção do status quo}

\subsection{As primeiras reformas do novo regime}

A mudança de regime político, iniciada com o golpe militar de 28 de Maio de 1926, veio provocar alterações de fundo nas políticas direccionadas para a instrução e a cultura, envolvendo, naturalmente, as bibliotecas e os arquivos. Os ideais republicanos em prol de uma cultura erudita, coexistindo com a instrução do povo, veiculada em grande parte pela difusão do livro e da leitura, por meio das bibliotecas populares, não vão ter seguidores no quadro do novo regime. Se bem que, numa primeira fase, a acção da Inspecção das Bibliotecas e Arquivos - ainda sob a alçada de um Júlio Dantas interveniente e colaborador activo com o novo poder político - vá ter uma expressão significativa, particularmente no delinear de um novo enquadramento legislativo, a breve trecho essa dinâmica vai esmorecer, em favor da rotina e da apatia que passam a caracterizar aquele organismo estatal.

As primeiras acçōes legislativas do novo regime ocorreram pouco tempo depois da tomada do poder em Maio de 1926 e tiveram um carácter acentuadamente restritivo, sendo justificadas por razôes financeiras e pela necessidade de racionalizar recursos, embora motivos de ordem político-ideológica tenham estado por detrás de muitas das medidas tomadas. Tal foi o caso da Biblioteca Nacional, onde o dinamismo técnico, editorial e cultural da sua direcção (a cargo de Jaime Cortesão), grandemente apoiada nos Serviços Técnicos chefiados por Raul Proença, constituíram, de imediato, um alvo a abater, dado o incómodo ideológico que causavam ao poder instituído. O facto de Proença e Cortesão serem figuras proeminentes do grupo da Seara Nova, claramente opositor ao regime imposto em 28 de Maio de 1926, e de não se coibirem de actuar em conformidade com os seus ideais genuinamente republicanos, rapidamente fez com que se tornassem alvos de perseguições e arguidos num processo que culminou 
com a sua demissão compulsiva da Biblioteca Nacional, o exílio e, no caso de Raul Proença, a insanidade mental nos últimos anos de vida 5 .

A remodelação intentada na Biblioteca Nacional, no sentido de um maior controlo político e de uma redução de despesas, efectivou-se por meio de alguns diplomas legislativos, promulgados no primeiro semestre de $1927^{6}$, e que tiveram por finalidade óbvia a resolução de problemas sentidos, especificamente, nesta instituição. Contudo, a reforma de fundo dos serviços das bibliotecas eruditas e arquivos não estava fora das preocupações do novo regime e também não se fez tardar. Ocorreu com a aprovação do Decreto n. ${ }^{\circ} 13.724$, de 27 de Maio de $1927^{7}$ e procurou abarcar não só os serviços, mas também aspectos de carácter técnico e a formação profissional.

O preâmbulo do referido diploma é elucidativo sobre as mudanças operadas num contexto de restrições económicas e preconiza medidas de acordo com a situação: "Um grande espírito de realidade domina os diplomas que o Govêrno hoje, promulga. As bibliotecas e os arquivos não podem parasitar na vida do País, pejando-se de empregados, envolvendo-se em riscos industriais; têm de se subordinar às dificuldades do Tesouro, aos seus recursos modestos, servindo com devoção o interêsse nacional" ${ }^{8}$. Nesta linha de pensamento e acção, o Estado promovia, através deste decreto, uma maior autonomia e descentralização dos serviços, mas entregava-os um pouco à sua sorte, demitindo-se dos encargos financeiros essenciais para assegurar a sua organização e funcionamento. Um outro extracto do preâmbulo do mesmo diploma deixa transparecer bem a política gizada para o sector:

"O conjunto de medidas, a seguir promulgadas, obedece a êsse escopo [refere-se às restriçôes financeiras]. Reduz-se consideràvelmente a despesa da Biblioteca Nacional, que financeiramente gozava duma situação privilegiada, sem o correspondente proveito do serviço e do pessoal de carreira, e transfere-se para outros estabelecimentos sempre sistemàticamente esquecidos o seu excedente. Alargam-se as atribuições dos chefes e sua competência disciplinar; melhora-se a situação do pessoal, procura-se dignificá-lo e estimular a sua dedicação. A Inspecção é dotada duma rêde de arquivos e delegados distritais, sem novos encargos para o Estado. Os serviços são simplificados e embaratecidos,

\footnotetext{
${ }^{5}$ A descrição pormenorizada dos últimos tempos em que Cortesão e Proença trabalharam na Biblioteca Nacional e o processo persecutório a que foram sujeitos pode-se ler em: Raul Proença: o caso da Biblioteca. Organização, estudos e notas de Daniel Pires e José Carlos González. Lisboa : Biblioteca Nacional, 1988.

${ }^{6}$ Vejam-se, em particular, os seguintes diplomas: Decreto n.o 13.151, de 15 de Fevereiro de 1927 , que extinguiu o lugar de director dos Serviços Técnicos da Biblioteca Nacional; Portaria n. ${ }^{4}$ 4.825, de 3 de Março de 1927, dispensando do serviço todo o pessoal assalariado da Biblioteca Nacional; Decreto n. ${ }^{\circ}$ 13.240, de 4 de Março de 1927, estabelecendo as condições de funcionamento dos serviços técnicos da Biblioteca Nacional; Decreto n. ${ }^{\circ}$ 13.420, de 2 de Abril de 1927, autorizando a Comissão Liquidatária da Tipografia da Biblioteca Nacional a mandar efectuar todos os trabalhos que julgasse necessários aos interesses do Estado; Decreto n. ${ }^{\circ}$ 13.490, de 18 de Abril de 1927, autorizando o Director da Biblioteca Nacional a pagar três meses de ordenado ao pessoal assalariado despedido em 3 de Março de 1927 e que não estivesse sujeito a sanções disciplinares.

7 PORTUGAL. Leis, decretos, etc. - Ministério da Instrução Pública: Direcção Geral do Ensino Superior: Decreto n. ${ }^{\circ}$ 13:724 [de 27 de Maio de 1927]. Diário do Govêrno. 1. a série. Lisboa. 114 (3 Jun. 1927) 881-901.

${ }^{8}$ PORTUGAL. Leis, decretos, etc. - Ministério da Instrução Pública: Direcção Geral do Ensino Superior: Decreto n. ${ }^{\circ} 13: 724 \ldots$ (ob. cit.) p. 881.
} 
de modo a apressar a actualização dos catálogos, a modernização das colecções, bem servindo as solicitações do público estudioso e ledor, que é o fim último de toda a organização bibliotecária e arquivística. Não se cria nenhum imposto novo, não se aumenta nenhum, antes se reduzem os do depósito obrigatório. Estabelece-se o princípio de que as administrações autónomas, dentro da sua liberdade e responsabilidade, devem diligenciar aliviar o Estado dos seus encargos. E, prevenindo a hipótese de que a execução dos presentes diplomas trouxesse, em contrário da previsão orçamental, algum aumento de despesa, o Ministro da Instrução Pública fica autorizado a reduzir vencimentos, gratificações e dotações até ao preciso para que tal agravamento não se dê"’.

A reforma de 1927 não procurou apenas legislar sobre a organização da Inspecção das Bibliotecas Eruditas e Arquivos e organismos dela dependentes (a biblioteca e o arquivo nacionais, a Biblioteca da Ajuda, a Biblioteca Pública de Braga e a Biblioteca Pública de Évora), no sentido de uma maior contenção administrativa e financeira, mas introduziu alguns aspectos inovadores. Um deles foi o previsto no art. $127 .{ }^{\circ}$, a saber: "Bienalmente, no mês de Maio e durante três dias, realizar-se há uma conferência inter-bibliotecária e arquivística, com o fim de discutir questôes de ordem técnica, divulgar os trabalhos efectuados, estabelecer a possível uniformidade de métodos e promover convívio com os investigadores”. Estas conferências deveriam estar sujeitas a um programa previamente fixado, sendo as suas actas e comunicaçōes publicadas nos Anais das Bibliotecas e Arquivos, órgão oficial da Inspecção ${ }^{10}$. Contudo, e apesar de entre 1927 e 1931 esta publicação não ter sido editada, não se encontram notícias da realização nem a publicação de quaisquer resultados das conferências inter-bibliotecárias e arquivísticas, previstas na lei.

Inovador foi, também, o facto de em anexo ao diploma serem publicadas as Normas para o serviço da catalogação, as quais se baseavam, naturalmente, no trabalho desenvolvido e posto em prática, na Biblioteca Nacional, por Raul Proença.

A par da reforma da Inspecção das Bibliotecas e Arquivos e dos organismos dela dependentes ocorreu a reestruturação dos serviços da Inspecção das Bibliotecas Populares e Móveis, através do Decreto n. ${ }^{\circ} 13.726^{11}$. Pretendia-se que "não só a Biblioteca Popular de Lisboa possa cumprir dentro da capital a sua alta missão, mas também que fique dotada com um sistema especial de serviços que lhe permita, gradualmente, lançar pelo País uma vasta rêde de leitura e cultura popular, utilizando para tal os recursos e regalias que se lhe vão facultar" ${ }^{12}$. Além disso, as bibliotecas populares passariam a ter receita própria "fornecida pelas regiōes que elas vão directamente interessar" ficando o Estado apenas "com o encargo de lhes dar o primeiro impulso, continuando a despender com elas pouco mais do que até agora estava gastando" 13 .

9 Idem, ibidem.

${ }^{10}$ Esta publicação teve início em Outubro de 1914, sob o título Anais das Bibliotecas e Arquivos de Portugal, tendo a 1. a série terminado em Abril de 1917. Uma 2. a série foi reactivada em Março de 1920, graças, sobretudo, à iniciativa de Raul Proença.

${ }^{11}$ PORTUGAL. Leis, decretos, etc. - Decreto n. ${ }^{\circ}$ 13:726 [de 27 de Maio de 1927]. Diário do Govêrno. 1. ${ }^{a}$ série. Lisboa. 114 (3 Jun. 1927) 918-921.

${ }^{12}$ PORTUGAL. Leis, decretos, etc. - Decreto n. ${ }^{\circ} 13: 726 \ldots$ (ob. cit.) p. 919.

13 Idem, ibidem. 
Esta mudança de perspectiva, pretensamente orientada para uma maior autonomia das bibliotecas populares, na prática, traduziu-se numa desresponsabilização do Estado relativamente a este sector, que tão caro havia sido à República, e acabou por não favorecer o desenvolvimento da rede de bibliotecas populares, que ficaram entregues a si mesmas e sem o apoio financeiro imprescindível para funcionarem adequadamente.

A perspectiva centralista, conservadora e de controlo, que começava paulatinamente a impor-se, manifestava-se também neste diploma, numa disposição claramente limitativa da liberdade de expressão e do acesso à informação. No art. 21. ${ }^{\circ}$ determinava-se que: "É absolutamente vedado fornecer ao público das bibliotecas populares e móveis quaisquer livros, revistas e panfletos que contenham doutrinas imorais e contrárias à segurança do Estado. A fiscalização do que se prescreve neste artigo cabe ao inspector das bibliotecas populares e móveis, ao director da Biblioteca Popular de Lisboa e a todos os cidadãos no pleno uso dos seus direitos políticos"14.

As primeiras medidas reformadoras do sector bibliotecário e arquivístico foram muito efémeras pois, quase de imediato, começou a ser preparada a grande reforma do Estado Novo para esta área, a qual veio a ser promulgada em 1931. Precedeu-a a criação de um novo serviço, inspirada por motivações de carácter ideológico bem em consonância com a visão que o regime veiculava. Estamos a referir-nos ao Arquivo Histórico Colonial (hoje Arquivo Histórico Ultramarino), instituído pelo Decreto n. ${ }^{\circ} 19.868$, de 9 de Junho de 1931, na dependência do Ministério das Colónias ${ }^{15}$. O diploma veio formalizar aquilo que já existia, de facto, há alguns anos, nas instalaçôes do Palácio da Ega, à Junqueira, com o nome de Arquivo Geral das Colónias e visava concentrar, num mesmo espaço, todos os arquivos do Ministério das Colónias, espalhados por diferentes locais.

Em plena época de instauração do Estado Novo, os jornais preocupavam-se em noticiar o novo serviço que, de algum modo, simbolizava a grandeza do império colonial e a prova de que o poder instituído tinha particular interesse neste organismo é que diversos membros do Governo e o próprio Presidente da República visitaram o Arquivo Histórico Colonial, contribuindo assim para a difusão na imprensa de um número significativo de notícias a esse respeito ${ }^{16}$.

${ }^{14}$ PORTUGAL. Leis, decretos, etc. - Decreto n. ${ }^{\circ} 13: 726 \ldots$ (ob. cit.) p. 920.

${ }^{15}$ PORTUGAL. Leis, decretos, etc. - Ministério das Colónias: Decreto n.o 19:868. Diário do Govêrno. 1. a série. Lisboa. 133 (9 Jun. 1931) 1.080-1.081.

${ }^{16}$ Ver, por exemplo: O Arquivo Colonial recebeu, ontem, a visita dos srs. Presidente da República e do Ministério e Ministro das Colónias. O Seculo. Lisboa. 50:17.486 (13 Nov. 1930) 12; O Arquivo Geral das Colónias foi ontem visitado pelo sr. Presidente da República e outras entidades oficiais. Diário de Notícias. Lisboa. 66:23.273 (13 Nov. 1930) 1; O Arquivo Histórico Colonial foi ontem visitado pelo Chefe de Estado e por alguns membros do Governo. A Voz. Lisboa. 6:1.351 (13 Nov. 1930) 6; No "Palácio da Ega": o Arquivo Histórico Colonial... Novidades. Lisboa. 45:10.839 (13 Nov. 1930) 1-2; No Palácio da Ega: o chefe do Estado visitou hoje o Arquivo Colonial. Diário de Lisboa. Lisboa. 10:2.943 (12 Nov. 1930) 8. 


\subsection{A "lei de bases" para o sector das bibliotecas e dos arquivos: o Decreto n. ${ }^{\circ} 19.952$}

A reforma mais estruturante do sector das bibliotecas e dos arquivos começou a ser gizada pouco tempo depois de promulgada a primeira legislação do novo regime, em 1927. Para o efeito, o Ministro da Instrução Pública nomeou uma comissão, presidida por Júlio Dantas, com o objectivo de "elaborar novo projecto de organização dos serviços bibliotecários e arquivísticos" ${ }^{17}$ e, assim, rever os decretos n. ${ }^{\circ} 13.724$ e 13.726 . A proposta de diploma, elaborada pelo próprio Júlio Dantas, só foi convertida em lei três anos depois de ser apresentada - numa altura em que se entrava já claramente num período de consolidação do regime -, consumando-se pelo Decreto n. ${ }^{\circ}$ 19.952, de 27 de Junho de $1931^{18}$. Nesta altura é já bem perceptível a atitude do Inspector. Atravessara toda a Primeira República na chefia da Inspecção das Bibliotecas Eruditas e Arquivos, pondo em prática uma política em muito diferente da que agora se perspectivava para o sector, mas aderira rapidamente às novas ideias do Estado Novo, valendo-lhe isso a continuidade no cargo até se aposentar, em $1946^{19}$.

O Decreto n. ${ }^{\circ} 19.952$ teve uma importância fundamental, pois deu enquadramento legal a reformas efectivas e constituiu a base da política biblioteconómica e arquivística de mais longa duração desde que fora instituída a Inspecção das Bibliotecas e Arquivos. Imbuída de um espírito fortemente centralista do ponto de vista político, a reforma de 1931 visou, antes de tudo, reorganizar a Inspecção "num sentido de grande amplificação das suas atribuições, tornando-se assim muito mais larga e fecunda a sua acção, que daqui em diante se fará sentir sôbre muitas bibliotecas e arquivos até agora completamente arredados dela" ${ }^{20}$. O preâmbulo do decreto exprime bem esse alargamento de funções, o qual, na realidade, era sobretudo um reforço do poder centralizador deste organismo, perspectiva em que ganhava todo o sentido a extinção da Inspecção das Bibliotecas Populares e Móveis, passando os serviços dela dependentes, entre os quais se destacava a Biblioteca Popular Central de Lisboa, a ser tutelados directamente pela Inspecção das Bibliotecas e Arquivos. Esta medida é justificada de uma forma bastante incisiva, nestes termos:

"Durante muito tempo foi costume considerar as bibliotecas populares como opostas às bibliotecas científicas e eruditas, e até como antagónicas destas. Tal orientação vai passando e, actualmente, em biblioteconomia, está prevalecendo cada vez mais uma

${ }^{17}$ Ver: DANTAS, Júlio - Criação e organização dos arquivos distritais. Anais das Bibliotecas e Arquivos. Lisboa. 2. ${ }^{\text {a }}$ série. 10:37/38 (Jan.-Jun. 1932) 9-10.

18 PORTUGAL. Leis, decretos, etc. - Ministério da Instrução Pública : Direcção Geral do Ensino Superior e das Belas Artes: Decreto n. ${ }^{\circ}$ 19:952. Diário do Govêrno. 1. a série. Lisboa. 147 (27 Jun. 1931) 1.253-1.269.

${ }^{19}$ O novo diploma reformador das bibliotecas e dos arquivos, bem como a proposta de criação do Arquivo Histórico Colonial são dois sinais evidentes da adesão de Júlio Dantas ao Estado Novo e reveladores da sua interpretação inequívoca da política oficial vigente. Não foi também por acaso que o Decreto n.o 19.952, no seu art. 16. ${ }^{\circ}$, tornou vitalícios os lugares de Inspector e Sub-inspector das bibliotecas e arquivos, os quais eram desempenhados, respectivamente, por Júlio Dantas e António Ferrão.

${ }^{20}$ PORTUGAL. Leis, decretos, etc. - Ministério da Instrução Pública : Direcção Geral do Ensino Superior e das Belas Artes : Decreto n. ${ }^{\circ}$ 19:952 (ob. cit.) p. 1.253. 
concepção muito diferente dessa. Bibliotecários eminentes, em importantes revistas da especialidade, como a Zentralblatt für Bibliothekswesen, têm mostrado que a técnica bibliotecária une êsses dois tipos de bibliotecas e que a ciência e a erudição só aparecem depois em discriminações de pormenor.

Assim, tudo leva a coordenar tais serviços: o lado técnico, bibliotecário, o aspecto económico e a dificuldade insuperável de saber onde acaba a leitura popular e começa a leitura científica e erudita.

Tais tipos de bibliotecas correspondem muito mais a uma questão de topografia da leitura, isto é, à necessidade de salas separadas para clientelas diferentes, do que a uma questão íntima, espiritual, cultural de núcleos biblíacos em armazéns ou depósitos separados" 21 .

Além da centralização das funções de orientação e de fiscalização dos arquivos e das bibliotecas, também se tomam medidas em favor da "uma melhor organização dos serviços". E, tendo em vista tal objectivo, estabelece-se uma classificação "tam rigorosa quanto possível, dêsses estabelecimentos, o que permite decidir com mais facilidade qual o destino a dar aos núcleos de manuscritos a encorporar e aos impressos a adquirir" 22 . Esta classificação visava também introduzir alguma economia na aquisição de bibliografia estrangeira, pois, segundo o legislador, agora seria possível "elaborar um plano de aquisiçôes de acôrdo com o carácter de cada biblioteca”, evitando-se, assim, a existência de duplicados numa mesma instituição.

Após um extenso preâmbulo em que se expõem, de forma aprofundada, as motivações para a reforma dos serviços das bibliotecas e dos arquivos e a visão do Governo para esta área, o articulado inicia-se com as disposições relativas à Inspecção das Bibliotecas e Arquivos, às quais se seguem as respeitantes aos inúmeros organismos dela dependentes, quer do ponto de vista administrativo, quer do ponto de vista técnico: Biblioteca Nacional de Lisboa; Arquivo Nacional da Torre do Tombo; Biblioteca da Ajuda; Biblioteca de Évora; arquivos distritais do Porto e de Coimbra; Arquivo Municipal de Guimarães; bibliotecas públicas de Braga, de Castelo Branco, de Vila Real e de Ponta Delgada; bibliotecas eruditas de Leiria e de Bragança; Biblioteca Popular Central de Lisboa; bibliotecas populares e móveis; arquivos e bibliotecas municipais e paroquiais; arquivos e bibliotecas dos institutos científicos do Estado, das universidades e de outros estabelecimentos de ensino superior; arquivos e bibliotecas dos estabelecimentos de ensino secundário, artístico, técnico, profissional e especial; arquivos dos ministérios, tribunais, hospitais e de outros estabelecimentos e serviços do Estado; bibliotecas hospitalares, prisionais e outras; salas públicas de jornais.

Seguem-se os títulos relativos à preparação profissional do pessoal dos arquivos e das bibliotecas, aos inventários e catálogos dos arquivos e bibliotecas do Estado e aos trabalhos de bibliografia portuguesa.

Como se pode perceber do elenco das disposições regulamentares enunciadas, o diploma de 27 de Junho de 1931 configura-se como uma verdadeira "lei de bases" para o sector bibliotecário e arquivístico. Tem uma abrangência até então nunca plasmada

${ }^{21}$ PORTUGAL. Leis, decretos, etc. - Ministério da Instrução Pública : Direcção Geral do Ensino Superior e das Belas Artes: Decreto n. ${ }^{\circ}$ 19:952 (ob. cit.) p. 1.254.

22 Idem, ibidem. 
na lei e procura abarcar todo o tipo de serviços de informação/documentação, inseridos numa classificação que é estabelecida, tanto para o sector das bibliotecas como para o sector dos arquivos.

$\mathrm{Na}$ parte final deste diploma, são consideradas algumas questões mais específicas (aspectos técnicos e formação profissional) e são incluídas umas "disposições gerais", relativas aos meios para fazer cumprir esta lei, bem como a futuros desenvolvimentos destinados a regulamentar aspectos particulares da mesma. O art. $189 .{ }^{\circ}$ prevê exactamente que "A Inspecção das Bibliotecas e Arquivos proporá ao Ministro da Instrução Pública, no prazo máximo de seis meses a contar da data de publicação dêste decreto, os regulamentos necessários para a sua mais completa e profícua execução"23. Contudo, promulgada a lei estruturante para o sector das bibliotecas e dos arquivos, o ritmo legislativo do regime nesta matéria abrandou significativamente e diminuiu imenso em número de diplomas, sobretudo se o compararmos com a produção que caracterizou a Primeira República Portuguesa, em que era dada uma importância crucial às questôes da instrução pública, aí inserindo a política arquivística e biblioteconómica. Deste modo, os prometidos diplomas regulamentares ficaram, na sua maioria, por aprovar.

O Decreto n. ${ }^{\circ} 19.952$ manteve-se em vigor durante mais de três décadas, regulando todos os aspectos da vida dos arquivos e das bibliotecas do País, mesmo dos que não dependiam directamente da tutela administrativa do Estado. A actividade da Inspecção, bem como a acção concreta do seu líder, o Inspector Júlio Dantas, vão paulatinamente perdendo dinamismo e a rotina tende a instalar-se. A Inspecção passa a centrar-se, sobretudo, na gestão corrente, não havendo iniciativas legislativas de grande impacto, a não ser, porventura, a criação de alguns arquivos distritais ${ }^{24}$ e, em 1937, do Arquivo Histórico do Ministério das Finanças ${ }^{25}$, com o objectivo de resolver o problema dos arquivos de secretarias de Estado oitocentistas, que já não puderam ser incorporados na Torre de Tombo, por falta de espaço, tendo ficado à guarda da Direcção-Geral da Fazenda Pública.

${ }^{23}$ PORTUGAL. Leis, decretos, etc. - Ministério da Instrução Pública : Direcção Geral do Ensino Superior e das Belas Artes : Decreto n. ${ }^{o}$ 19:952 (ob. cit.) p. 1.269.

${ }^{24}$ Em 30 de Dezembro de 1931 foram reguladas as condiçōes de funcionamento do Arquivo Distrital do Funchal, já criado pelo Decreto n. 19.952 (cf.: PORTUGAL. Leis, decretos, etc. - Ministério da Instrução Pública : Direcção Geral do Ensino Superior e das Belas Artes : Repartição do Ensino Superior e das Belas Artes : Decreto n.o 20:690. Diário do Govêrno. 1. a série. Lisboa. 300 (30 Dez. 1931) 2.778-2.779; em 21 de Janeiro de 1932 foi criado o Arquivo Distrital de Viseu (cf.: PORTUGAL. Leis, decretos, etc. - Ministério da Instrução Pública : Direcção Geral do Ensino Superior e das Belas Artes : Repartição do Ensino Superior e das Belas Artes : Decreto n. ${ }^{\circ}$ 20:803 [de 21 de Janeiro de 1932]. Diário do Govêrno. 1. ${ }^{a}$ série. Lisboa. 18 (22 Jan. 1932) 178-179); em 13 de Fevereiro de 1933 foi criado o Arquivo Distrital de Portalegre (cf.: PORTUGAL. Leis, decretos, etc. - Ministério da Instrução Pública : Direcção Geral do Ensino Superior e das Belas Artes : Repartição do Ensino Superior e das Belas Artes : Decreto n. ${ }^{\circ} 22: 189$. Diário do Govêrno. 1. a série. Lisboa. 35 (13 Fev. 1933) 175-176); em 20 de Abril de 1948 foi criado o Arquivo Distrital de Angra do Heroísmo (cf. PORTUGAL. Leis, decretos, etc. - Ministério da Educação Nacional : Direcção Geral do Ensino Superior e das Belas-Artes : Decreto-lei n.o 36:842. Diário do Governo. 1. ${ }^{a}$ série. Lisboa. 91 (20 Abr. 1948) 316-317).

${ }^{25}$ PORTUGAL. Leis, decretos, etc. - Ministério das Finanças : Direcção Geral da Fazenda Pública : Decreto-lei n.o 28.127. Diário do Govêrno. 1. ${ }^{a}$ série. 268 (17 Nov. 1937) 1.217-1.219. 
Sobre a questão dos arquivos distritais, o próprio Júlio Dantas manifesta a sua preocupação, num relatório datado de 2 de Maio de 1932, que envia ao Director Geral do Ensino Superior ${ }^{26}$. Considerando que o diploma de 1931 "representa um notável passo dado no sentido da instituïção da rêde de arquivos distritais que o País reclama", diz o seguinte: "Quere isto dizer que o decreto n. ${ }^{\circ}$ 19:952 resolveu o problema dos arquivos distritais em Portugal? Infelizmente não. Decorridos quási dez meses sôbre a sua promulgação, eu apenas pude enviar a V. Ex. ${ }^{a}$ os projectos de decreto instituindo o Arquivo Distrital de Ponta Delgada, já criado de facto, embora não de direito, por acôrdo entre esta Inspecção e a Junta Geral Autónoma; o Arquivo Distrital do Funchal, que o diploma orgânico n. ${ }^{\circ}$ 19:952 incluíra no número dos arquivos distritais existentes [artigo 10. ${ }^{\circ}$, alínea $i$ )], esquecendo-se, entretanto, de definir e de assegurar as suas condições de organização e de funcionamento; e o Arquivo Distrital de Viseu" 27. E mais adiante: "O facto de se haver limitado à criação dos três arquivos, que acabo de citar, a actividade da Inspecção durante quási dez meses, significa que esta Repartição encontrou, por parte das juntas gerais e das comissões administrativas dos municípios, dificuldades que até agora não pôde vencer, e que dizem respeito, quer à cedência de edifícios para instalação dos arquivos distritais, quer à inscrição, nos respectivos orçamentos, das verbas necessárias para ocorrer aos encargos dêsses novos serviços" 28 .

Seguidamente, o inspector descreve as diligências feitas e os obstáculos encontrados em cada um dos distritos, impeditivos do desenvolvimento da rede de arquivos distritais projectada para o País, para concluir o seu relatório com a convicção de que o que restava fazer só poderia "entrar no domínio das realidades quando as condiçôes do Tesouro Público permitirem que o Estado chame a si todos os encargos administrativos dos arquivos distritais existentes, e daqueles que seja necessário ainda criar" 29 .

\subsection{As iniciativas no plano técnico}

Apesar dos constrangimentos e limitaçôes que cercearam a actividade da Inspecção nos anos subsequentes, as iniciativas no plano técnico merecem ser realçadas, embora se devam, quase exclusivamente, a António Ferrão, nomeado para o cargo de sub-inspector em 1929 e provido na chefia máxima da Inspecção, em 1946, após a aposentação de Júlio Dantas.

A acção da Inspecção após a promulgação da importante reforma de 1931 pode ser atestada por diversos escritos, designadamente os memorandos ou crónicas publicados nos Anais das Bibliotecas e Arquivos $^{30}$ ou os relatórios do Inspector Geral,

${ }^{26}$ Este relatório foi posteriormente publicado nos Anais das Bibliotecas e Arquivos (ver: DANTAS, Júlio - Criação e organização dos arquivos distritais (ob. cit.).

${ }^{27}$ DANTAS, Júlio - Criação e organização dos arquivos distritais (ob. cit.) p. 10.

${ }^{28}$ Idem, ibidem.

${ }^{29}$ DANTAS, Júlio - Criação e organização dos arquivos distritais (ob. cit.) p. 13.

${ }^{30}$ PORTUGAL. Inspecção Geral das Bibliotecas e Arquivos - Nota sumária de alguns assuntos mais importantes tratados em ofícios e relatórios... durante os meses de Setembro, Outubro, Novembro e Dezembro de 1931... Anais das Bibliotecas e Arquivos. Lisboa. 2. a série. 9 (1931) 104-106; PORTUGAL. Inspecção Geral 
relativos a inspecções aos estabelecimentos dependentes, também datados de $1932^{31}$. Igualmente importante é o testemunho de António Ferrão, dado no relatório que elaborou em Setembro de 1931, referente ao período de tempo em que substituiu, interinamente, o Inspector Júlio Dantas, à frente do organismo coordenador das bibliotecas e arquivos ${ }^{32}$.

Estes escritos, de par com os textos publicados na época em que António Ferrão assumiu as funções de Inspector são as fontes de informação mais ilustrativas da actividade da Inspecção, em todas as suas vertentes, a qual procurou sempre situar-se dentro do quadro legal do Decreto n. ${ }^{\circ}$ 19.952, de 1931.

Embora a dinâmica da Inspecção tenha esmorecido ao longo dos anos, a verdade é que, no que toca aos aspectos técnicos e normativos, houve algumas iniciativas dignas de nota, apesar das consequências práticas dessas medidas não se terem feito sentir de forma significativa.

Em matéria de tratamento técnico documental e no sentido de melhorar o estado do acesso à informação, incumbia-se a Junta Consultiva das Bibliotecas e Arquivos, entre outras coisas, de "estudar o regime geral da catalogação, bem como de organização de índices, inventários e roteiros para os estabelecimentos dependentes da Inspecção" 33, percebendo-se claramente que as "Regras de Catalogação" elaboradas por Raul Proença e postas em prática na Biblioteca Nacional haviam já sido banidas como instrumento de normalização, se bem que ainda continuassem em uso na instituição onde foram geradas.

Além disto, é ainda de realçar o trabalho desenvolvido com vista à identificação e caracterização dos serviços detentores de documentação: o inquérito às bibliotecas municipais, levado a cabo por António Ferrão, em 1932-1933, o qual permitiu concluir que a sua situação era "lamentável"; o projecto de inquérito, elaborado em 1943, por iniciativa de Júlio Dantas, mas do qual foi encarregado, de novo, o sub-inspector António Ferrão, e que se destinava a todos os organismos detentores de acervos documentais, incluindo as "Ilhas adjacentes" e o "Império Colonial"; e um novo inquérito, promovido em 1946, ocupando já António Ferrão o cargo de Inspector.

Como já sucedera em épocas anteriores, as acções de diagnóstico promovidas pela Inspecção eram levadas a efeito com bastante rigor e empenho, mas as consequências naturais deste trabalho, que deveriam saldar-se em medidas concretas para melhoria da deficiente situação detectada, nunca chegaram a efectivar-se.

Nos anos subsequentes, à excepção do período em que António Ferrão dirigiu a Inspecção das Bibliotecas e Arquivos (1946-1954), nada de relevante merece ser assinalado. Nesta fase, porém, o estudo e a reflexão, plasmados em inúmeros relatórios técnicos enviados à tutela, atingiram um nível nunca antes alcançado, mas não lograram

das Bibliotecas e Arquivos - Alguns assuntos mais importantes tratados em ofícios e relatórios... durante o primeiro semestre de 1932. Anais das Bibliotecas e Arquivos. Lisboa. 2. a série. 10 (1932) 75-81.

${ }^{31}$ DANTAS, Júlio - Relatórios do Inspector Geral : inspecçôes a arquivos. Anais das Bibliotecas $e$ Arquivos. Lisboa. 2.a série. 10 (1932) 121-133.

32 FERRÃO, António - Alguns serviços dos arquivos e bibliotecas do Estado : relatorio. Lisboa : [s. n.], 1932. (Originalmente publicado em: Diário do Govêrno. 2.a série. Lisboa. 13 (16 Jan. 1932) 216-223.)

33 PORTUGAL. Leis, decretos, etc. - Ministério da Instrução Pública : Direcção Geral do Ensino Superior e das Belas Artes : Decreto n. ${ }^{\circ} 19: 952$ (ob. cit.) art. 25. ${ }^{\circ}, \$ 6 .^{\circ}$, p. 1.258. 
atingir a efectiva concretização, pois o despacho superior exarado nas propostas de António Ferrão, quase invariavelmente, resumia-se a um lacónico “Aguarde”.

\subsection{A formação profissional}

Um outro aspecto que merece ser relevado é o da reorganização do Curso Superior de Bibliotecário-Arquivista, numa perspectiva muito mais centralista, aliás, em consonância com a generalizada reforma da administração pública. Passava agora a ser um "curso exclusivamente profissional" 34 , tendo sofrido, em conformidade, uma redução curricular. Passou a ter a duração de apenas dois anos e a incluir um elenco de disciplinas muito mais reduzido ${ }^{35}$.

Uma outra alteração significativa operada teve a ver com as condiçôes de acesso ao curso (agora inteiramente dependente da Inspecção das Bibliotecas e Arquivos e já não da Faculdade de Letras da Universidade de Lisboa), que passava a ter estatuto de curso de pós-graduação. Contudo, esta maior "profissionalizaçãa” do Curso teve uma duração breve, pois em 1935, um novo diploma fê-lo regressar à Universidade (desta vez, à Faculdade de Letras da Universidade de Coimbra), onde se manteve inalterado durante quase meio século, ou seja, até 1982, ano em que foi extinto. A sua concepção assentava numa visão erudita que revelava que a formação dos bibliotecários e arquivistas continuava a ser moldada pela matriz histórico-tecnicista que desde a Revolução Francesa se fora desenvolvendo e consolidando de forma paradigmática.

A evolução internacional, marcada pelo desenvolvimento da informação científica e técnica e pela associação das novas tecnologias ao tratamento da informação, que, sobretudo após a Segunda Guerra Mundial, passou a influenciar os modelos formativos, quer na Europa, quer nos Estados Unidos da América, tardou a produzir efeitos em Portugal. A situação política do País durante o período do Estado Novo, caracterizada por um isolamento relativamente ao exterior, não favoreceu os contactos internacionais nem o acompanhamento da evolução que se verificava na Arquivística, na Biblioteconomia e em novas áreas como a Documentação e a Ciência da Informação (Information Science), em franco desenvolvimento desde o final dos anos cinquenta do século XX. A consciência do atraso que se vivia em Portugal, nomeadamente por parte da classe profissional, conseguiu impulsionar a criação de um modelo de formação alternativo ao velho Curso de Bibliotecário-Arquivista, que se traduziu na criação, em $1969^{36}$, de um Estágio destinado à preparação técnica de bibliotecários, arquivistas e documentalistas, o qual conferia também habilitação própria para o desempenho

${ }^{34}$ PORTUGAL. Leis, decretos, etc. - Ministério da Instrução Pública : Direcção Geral do Ensino Superior e das Belas Artes : Decreto n. ${ }^{\circ}$ 19:952 (ob. cit.) p. 1.254.

${ }^{35}$ As disciplinas eram as seguintes: Bibliologia (um semestre), Biblioteconomia (um semestre), Arquivologia e Arquivo-economia (um semestre), Paleografia (um ano), Diplomática e Esfragística (um ano), Numismática e Medalhística (um semestre) e Iconografia e Iluminura (um semestre) - cf.: PORTUGAL. Leis, decretos, etc. - Ministério da Instrução Pública : Direcção Geral do Ensino Superior e das Belas Artes: Decreto n. ${ }^{\circ} 19: 952$ (ob. cit.) art. $160 .^{\circ}$, p. 1.267.

36 PORTUGAL. Leis, decretos, etc. - Ministério da Educação Nacional : Direcção-Geral do Ensino Superior e das Belas-Artes : Decreto-lei n. ${ }^{4} 9.009$ [de 7 de Maio de 1969]. Diário do Governo. 1. a série. Lisboa. 116 (16 Maio 1969) 537-538. 
das funções que, até então, eram asseguradas somente pelo curso de bibliotecário-arquivista. Mas, apesar da existência desta outra modalidade de formação, o curso instituído, em 1935, na Faculdade de Letras da Universidade de Coimbra, continuava a ser o modelo dominante, mantendo um figurino clássico bem em consonância com a formação académica coimbrã.

\section{Da inoperância à extinção}

A Lei n. ${ }^{\circ} 1.941$, de 11 de Abril de $1936^{37}$, dera enquadramento a uma reestruturação do Ministério da Instrução Pública, que passara a denominar-se Ministério da Educação Nacional, e criara a Junta Nacional da Educação, órgão técnico e consultivo ao qual competiam os problemas inerentes à formação do carácter, ao ensino e à cultura. $\mathrm{Na} 6{ }^{\text {a }}$ secção, Belas Artes, era incluída uma sub-secção, intitulada "Literatura, Bibliotecas e Arquivos", cuja vice-presidência cabia ao Inspector Superior das Bibliotecas e Arquivos. A esta sub-secção eram adstritas competências técnicas, em que se inseriam, entre outras, a de promover a inventariação e catalogação das espécies documentais e a elaboração do catálogo colectivo das bibliotecas portuguesas, dois objectivos recorrentes em todas as reformas legislativas promulgadas desde a criação da Inspecção, mas permanentemente adiados na sua concretização.

Contudo, este facto não veio contribuir para que novas medidas de fundo fossem tomadas pela Inspecção. As preocupaçôes historicistas continuavam a ser um dos aspectos dominantes, particularmente no tocante aos arquivos, mas as acções efectivas também não se concretizavam, quer por constrangimentos orçamentais, quer por falta de vontade política. A criação dos arquivos distritais, por exemplo, acontecia a uma ritmo confrangedor.

Após a retirada de António Ferrão do cargo de Inspector, a gestão corrente passou a dominar a actividade da Inspecção, não se concretizando iniciativas dignas de referência. $\mathrm{Na}$ verdade, foi esmorecendo paulatinamente, sendo apropriado usar as palavras de Mesquita de Figueiredo aplicadas ao Arquivo Nacional nos princípios do século: o "estado de torpor" instalara-se no organismo tutelar das bibliotecas e dos arquivos.

O dirigente que sucedeu a António Ferrão no cargo de Inspector foi o bibliotecário-arquivista Luís Silveira, que havia sido Director da Biblioteca Pública de Évora. Procurou, nos primeiros tempos, promover algumas iniciativas, sendo de referir o relançamento dos Anais. Mas, em contraste com o que fora esta publicação no tempo de António Ferrão, a nova série assumiu muito mais o carácter de revista cultural erudita do que o de uma publicação técnico-científica de Biblioteconomia e Arquivística.

Além disso, representou Portugal em diversos encontros internacionais, mas apesar da importância de que se revestiam tais eventos, particularmente num período em que o País vivia isolado da Europa, a verdade é que a participação nessas reuniōes internacionais se saldava mais numa presença pessoal do Inspector do que numa representação institucional, não tendo, portanto, quaisquer repercussões nos meios arquivísticos e biblioteconómicos portugueses.

${ }^{37}$ PORTUGAL. Leis, decretos, etc. - Ministério da Instrução Pública : Lei n. ${ }^{o}$ 1:941. Diário do Govêrno. 1. a série. Lisboa. 84 (11Abr. 1936) 411-413. 
Uma outra iniciativa que importa assinalar, nos primeiros anos do seu mandato, foi a tentativa de elaboração de um roteiro completo e actualizado das bibliotecas e dos arquivos de Portugal ${ }^{38}$, dado que a falta deste roteiro "era grave e impeditiva de progresso firme" dos seus trabalhos no desempenho do cargo de Inspector Superior das Bibliotecas e Arquivos. Mas, a intenção declarada nos Anais - "todos os trabalhos em curso, cujos resultados irão sendo expostos sistemàticamente, abrangem, como fica dito, todas as bibliotecas portuguesas e darão elementos de apreciação e estudo, tanto de ordem quantitativa como qualitativa, tão extensa, completa e desenvolvidamente quanto nos for possível" 39 - não passou, na verdade, de isso mesmo: uma intenção.

A partir desta época, não há quaisquer desenvolvimentos ou iniciativas relevantes, tendo a Inspecção entrado numa apatia que acabou por conduzir à reforma legislativa de 1965. Com efeito, dois diplomas datados de 22 de Maio desse ano vão promover uma alteração estrutural ao quadro vigente desde 1931: por um lado, a promulgação do Regimento da Junta Nacional da Educação, em cujas secçôes se incluía uma especificamente dedicada às bibliotecas e arquivos ${ }^{40}$; por outro, uma reestruturação "vasta e profunda" neste sector, que extinguiu a Inspecção como organismo autónomo e reequacionou as políticas a pôr em prática daí em diante ${ }^{41}$.

O elenco de atribuiçôes cometidas à Junta Nacional da Educação é elucidativo do que continuava por realizar, particularmente no que respeitava à disponibilização para consulta pública de documentos que o Estado custodiava e que tinha obrigação de tornar acessíveis. Afinal, a política incorporacionista - iniciada ainda no século XIX, mas prosseguida pela Primeira República e pelo Estado Novo -, ao abrigo da qual tinham passado para a tutela estatal incomensuráveis quantidades de documentação, não vira concretizado um dos seus desideratos fundamentais: tornar público e acessível o que era de todos os cidadãos.

$\mathrm{O}$ inconformismo dos profissionais dos arquivos e bibliotecas, relativamente à situação de imobilismo que afectava o sector bibliotecário e arquivístico trouxe à luz os seus efeitos no início da década de 60. Começaram a organizar-se e a tornar públicas as suas preocupações através de uma publicação de carácter técnico - os Cadernos de Biblioteconomia e Arquivistica ${ }^{42}$-, nascida em 1963, que passou a ser um pólo em torno do qual um grupo desencadeou uma dinâmica tendente a pôr em marcha um processo

\footnotetext{
${ }^{38}$ Foi, pelo menos, a quinta vez que, por iniciativa da Inspecção, se realizou um inquérito de diagnóstico da situação das bibliotecas e dos arquivos.

39 SILVEIRA, Luís - Roteiro das bibliotecas e dos arquivos de Portugal : situação das bibliotecas municipais do continente. Anais das Bibliotecas e Arquivos de Portugal. Lisboa. 3. ${ }^{a}$ série. 1 (1958) XVIII.

40 PORTUGAL. Leis, decretos, etc. - Decreto n. ${ }^{\circ} 46$ 349. Diário do Governo. 1. a série. Lisboa. 114 (22 Maio 1965) 711-718.

${ }^{41}$ PORTUGAL. Leis, decretos, etc. - Direcção-Geral do Ensino Superior e das Belas-Artes : Decreto n.o 46 350. Diário do Governo. 1. a série. Lisboa. 114 (22 Maio 1965) 718-724 (com uma rectificação em: Diário do Governo. 1. ${ }^{a}$ série. Lisboa. 132 (14 Jun. 1965) 828). Este diploma pode também ser consultado em: Organização dos serviços das bibliotecas e arquivos : Decreto-Lei n.o 46.350. Bibliotecas e Arquivos de Portugal. Lisboa. 1 (1969) 233-255.

${ }^{42}$ Esta publicação passou, mais tarde, a designar-se Cadernos de Biblioteconomia, Arquivistica $e$ Documentação, título que ainda hoje mantém, sendo abreviadamente referida como "Cadernos BAD”.
} 
de renovação que se prolongou por muitos anos ${ }^{43}$ e que, sem dúvida, contribuiu para a promulgação do Decreto-Lei n. ${ }^{0} 46.350$, de 22 de Maio de 1965, que reformou o sector bibliotecário e arquivístico do Estado.

Este diploma explicita, claramente, no seu preâmbulo, as motivaçôes que estiveram na origem da sua aprovação, nomeadamente a actualização que urgia empreender, visto que o regime legal em vigor tinha já mais de três décadas. Reconhece-se, inequivocamente, o estado de atraso que as bibliotecas e os arquivos conheciam, bem como as deficiências na sua organização e funcionamento, dizendo-se: “... os nossos serviços bibliotecários e arquivísticos estão muito longe de cumprir a sua missão. Núcleos importantes do nosso património documental se encontram espalhados por todo o País sem que se lhes dispensem os mais elementares cuidados de guarda e conservação. Por outro lado, os nossos estabelecimentos continuam a ter os seus fundos incompleta e defeituosamente inventariados e catalogados, quando não estão convertidos em simples armazéns de papéis e livros sobre que não se exerceu ainda o mais leve trabalho de reconhecimento" ${ }^{44}$.

Para tornar mais eficaz a política que se delineava para o sector, foi decidido alterar a subordinação orgânica dos serviços até então dependentes da Inspecção das Bibliotecas e Arquivos - considerada neste diploma como "um organismo simultâneamente burocrático e técnico" -, passando-os para a dependência directa da Direcção-Geral do Ensino Superior e das Belas-Artes, ou seja, extinguindo a figura da Inspecção como organismo coordenador das bibliotecas e arquivos e de toda a política nesta área ${ }^{45}$. O legislador assume peremptoriamente a necessidade de alterar a situação vigente: "Tem de modificar-se este regime, que oferece os mais sérios inconvenientes. Por um lado, absorvendo com exigências puramente administrativas grande parte do esforço do pessoal, leva a sacrificar as mais importantes formas de actividade técnica. Por outro, reduzindo frequentemente a Inspecção no domínio burocrático ao papel de mera estância de transmissão, de simples ponte de passagem entre os estabelecimentos e a Direcção-Geral, conduz a inútil duplicação de formalidades e a consequente demora na resolução dos assuntos" 46 .

Assim, a reforma de 1965 pôs fim a um ciclo em que a Inspecção das Bibliotecas e Arquivos tinha um papel decisivo em tudo quanto a estes organismos dizia respeito. O dinamismo que caracterizara a sua actividade até meados da década de trinta e no período da tutela de António Ferrão contrastou com os últimos anos da sua vigência, pautados pela inoperância e imobilismo que acabaram por conduzir à sua extinção.

43 Sobre a actividade dos profissionais nesta época, ver: REAL, Manuel Luís - Gestão do património arquivístico nacional. In: CONGRESSO NACIONAL DE BIBLIOTECÁRIOS, ARQUIVISTAS E DOCUMENTALISTAS, 2. ${ }^{\circ}$, Coimbra, 1987 - A Integração europeia : um desafio à informação : actas. Coimbra : Livraria Minerva, 1987. p. 207-246.

44 Organização dos serviços das bibliotecas e arquivos (ob. cit.) p. 234.

${ }^{45}$ A Direcção-Geral passava a exercer "todas as atribuições, faculdades e poderes conferidos pela legislação anterior à Inspecção Superior das Bibliotecas e Arquivos que não tenham passado para outro órgão ou serviço" (cf.: Organização dos serviços das bibliotecas e arquivos (ob. cit.) p. 244).

46 Organização dos serviços das bibliotecas e arquivos (ob. cit.) p. 235. 